\title{
Model Mitigasi Risiko pada Lembaga Penjamin Kredit di Indonesia*
}

\author{
Siti Zulaekhah** \\ Hukum Investasi dan Perbankan, Fakultas Hukum, Universitas Pekalongan \\ Jl. Sriwijaya No. 3 Pekalongan, Propinsi Jawa Tengah, 51111
}

\section{Abstract}

In Indonesia there are two types of credit schemes, both credit with collateral and guarantee scheme. This study aims, describes the construction of credit-based credit agreement law and constructs a risk mitigation model.This study used a doctrinal approach that the data being studied is limited to secondary dominated by primary legal materials. Qualitative analysis method based on the theory of stage by testing the level of horizontal synchronization between the Insurance with the Guarantee Act. The results showed, credit with guarantee scheme is an expansion of the provisions of subrogation and debt coverage as stipulated in the Civil Code.

Keywords: risk mitigation, re-insurance, collateral, credit agreement.

\section{Intisari}

Di Indonesia dikenal dua jenis skema kredit yang terdiri atas kredit dengan skema agunan (collateral) dan kredit dengan skema penjaminan. Penelitian ini bertujuan mendeskripsikan konstruksi hukum perjanjian kredit dan mengkonstruksi model mitigasi risiko pada lembaga penjamin kredit. Penelitian dilakukan dengan pendekatan doktrinal dan konsekuensianya data yang diteliti sebatas data sekunder yang didominasi oleh bahan hukum primer. Metode analisis kualitatif berbasis pada teori tangga dengan menguji taraf sinkronisasi horizontal antara Undang-Undang Perasuransian dengan Undang-Undang Penjaminan. Hasil penelitian menunjukkan, kredit dengan skema penjaminan merupakan perkembangan dari ketentuan subrogasi dan penanggungan utang menurut KUHPerdata. Namun lembaga ini memiliki kekhususunan berupa kewajiban mitigasi risiko.

Kata Kunci : mitigasi risiko, penjaminan ulang, reasuransi, collateral, perjanjian kredit.

\section{Pokok Muatan}

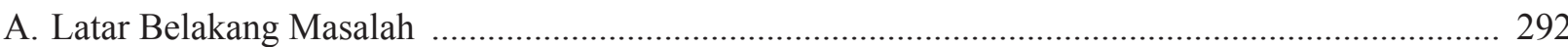

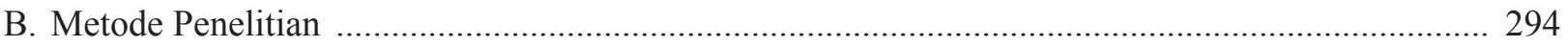

C. Hasil Penelitian dan Pembahasan ........................................................................................... 295

1. Konstruksi Hukum Perjanjian Kredit dengan Kredit Penjaminan Relevansinya dengan

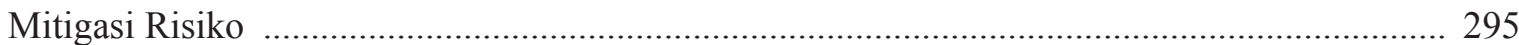

2. Model Mitigasi Risiko pada Perjanjian Penjaminan Kredit di Indonesia ................................. 299

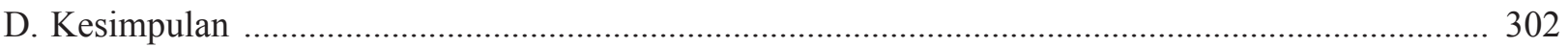




\section{A. Latar Belakang Masalah}

Melalui Pasal 33 ayat (4) Undang-

Undang Dasar Negara Republik Indonesia Tahun 1945 tersimak bahwa perekonomian nasional diselenggarakan berdasarkan atas demokrasi ekonomi dengan prinsip kebersamaan, efisiensi berkeadilan, berkelanjutan, berwawasan lingkungan, kemandirian, serta dengan menjaga keseimbangan kemajuan dan kesatuan ekonomi nasional. Demokrasi merupakan sarana untuk mewujudkan kesejahteraan masyarakat yang memerlukan dukungan dari berbagai pihak. Demokrasi ekonomi bercirikan bahwa semua pelaku usaha mendapatkan posisi dan peluang yang sama untuk menggerakkan roda perekonomian dengan tetap mengutamakan kebersamaan sebagai salah satu ciri ekonomi yang dicita-citakan pendiri bangsa.

Salah satu kelompok pelaku usaha yang turut berperan dalam menjalankan demokrasi ekonomi adalah Usaha Mikro, Kecil, Menengah, dan Koperasi (UMKM). Namun, kelompok pelaku usaha yang dominan di Indonesia dalam kegiatan usahanya menemui beberapa kendala dan kendala yang paling mendasar adalah keterbatasan akses terhadap lembaga kredit atau pembiayaan. Untuk mendapatkan posisi dan peluang yang sama, pelaku usaha ini harus mendapatkan perhatian, utamanya dari pemerintah yang ditekankan pada strategi penyediaan dana tanpa dibatasi syarat ketersediaan agunan yang ketat yang selama ini mejadi parameter lembaga perbankan sebagai basis prinsip kepercayaan.

Hadirnya lembaga penjamin di Indonesia dilatarbelakangi oleh ketidakmampuan sebagian kelompok pelaku usaha dalam menyediakan agunan dan ketiadaan administrasi yang baik terkait dengan kegiatan usahanya sehingga dinilai tidak memenuhi syarat kredit bank (bankable). Sebagai upaya untuk mengatasi permasalahan para pelaku usaha untuk mendapatkan kredit tanpa agunan, pemerintah telah megeluarkan kebijakan skema penjaminan kredit pada tahun 1970 dengan membentuk Lembaga Jaminan Kredit Koperasi (LJKK). Untuk mengukuhkan dan memberikan keyakinan kegiatan usaha penjaminan, pemerintah melalui Menteri Keuangan menerbitkan Peraturan Menteri Keuangan Nomor: 222/PMK.010/ 2008 tentang Perusahaan Penjaminan Kredit dan Perusahaan Penjaminan Ulang Kredit yang kemudian diperbarui dengan peraturan yang sama bernomor: 99/PMK.010/2011 tentang Perusahaan Penjaminan Kredit dan Perusahaan Penjaminan Ulang Kredit.

Skema kredit melalui mekanisme ini tidak berbasis pada collateral ( agunan) sebagai dasar kepercayaan kreditur kepada debitur, akan tetapi disandarkan oleh kehadiran lembaga penjaminan yang akan menjamin kreditur atas utang terjamin. Konsekuensinya, apabila terjadi cidera janji (wanprestatie) maka terjadi pengambilalihan risiko dari penerima jaminan ke lembaga penjamin. Sebagai dasar keyakinan para pihak terhadap peran dan kiprah lembaga penjaminan dalam skema kredit ini, maka terdapat kewajiban lain berupa mitigasi risiko sebagaimana diatur dalam UU No. 1 Tahun 2016 tentang Penjaminan. ${ }^{1}$

Sebelum diterbitkannya undang-undang tersebut, beberapa hasil penelitian menunjukkan kelemahan lembaga penjaminan di Indonesia karena tanpa disertai kewajiban mitigasi risiko sebagai dasar keyakinan para pihak, utamanya kreditur. Hasil penelitian Pusat Penelitian Pengembangan Badan Pembinaan Hukum Nasional (Puslitbang BPHN $)^{2}$ menunjukkan, lembaga penjamin kredit yang ada tidak optimal dalam menjalankan fungsinya karena keterbatasan sistem permodalan dan kapasitas lembaga penjamin perlu ditingkatkan peranan dan kapasitasnya.

Sementara itu, pada lingkup pemerintah daerah, baik pemerintah kabupaten maupun 
pemerintah kota, diselenggarakan Lembaga Penjamin Kredit Daerah (LKPD) untuk memfasilitasi serta mempermudah para pengusaha lokal dalam mengakses kredit. Pentingnya LKPD tersebut menurut penelitian Pradana $^{3}$ dianggap penting karena akan berbagi tugas dengan perbankan dalam hal penanganan kredit macet. Bank yang berkedudukan sebagai lembaga intermediasi sangat memerlukan adanya subsidi pada portofolio kredit bagi UMKM untuk melakukan mitigasi risiko. Berdasarkan penelitian tersebut, sudah mulai terfikirkan pentingnya penerapan prinsip mitigasi risiko dalam lembaga perbankan.

Hasil penelitian Bank Indonesia (BI) juga menguatkan kemungkinan sistem penjaminan kredit dapat mengalami kerugian. Untuk mengantisipasi kerugian ini, penulis berpendapat perlunya lembaga sejenis sebagai antisipasi kemungkinan kesulitan bahkan kegagalan lembaga penjamin dalam memenuhi kewajiban finansialnya kepada kreditur.

Beberapa kekhawatiran pihak-pihak yang menaruh perhatian pada kemungkinan risiko yang dihadapi para pihak dalam perjanjian kredit diakomodir dalam UU No. 1 Tahun 2016. Undangundang ini memuat pengaturan kewajiban mitigasi risiko dalam kegiatan penjaminan yang dibebankan kepada dua lembaga yaitu lembaga penjamin ulang dan lembaga reasuransi. Apabila lembaga penjamin tersebut tidak mendapat dukungan dari lembaga penjamin ulang, maka penjaminan ulang ini dilakukan oleh perusahaan reasuransi. Hal ini berarti undang-undang tersebut memperluas lingkup mitigasi risiko. Ketentuan tersebut mengandung arti bahwa apabila lembaga penjamin tidak mendapat dukungan keuangan dari lembaga penjaminan ulang maka mitigasi risiko diambil alih oleh perusahaan reasuransi .

Terkait hal ini, Pasal 1 angka 7 UndangUndang No. 40 Tahun 2014 tentang Perasuransian ${ }^{4}$ mengatur bahwa perusahaan penjaminan merupakan salah satu objek jasa pertanggungan ulang terhadap risiko yang mungkin dihadapi oleh perusahaan tersebut.

UU No. 40 Tahun 2014 tentang Perasuransian memuat pengaturan lingkup jasa pertanggungan ulang yang membenarkan keberadaan lembaga reasuransi sebagai bentuk mitigasi risiko terhadap pernjaminan kredit. Materi pengaturan ini menjadi catatan kritis keterkaitan dan sinkronisasi antar peraturan perundang-undangan dimana keberadaan lembaga reasuransi tersebut tidak dijadikan sebagai kajian teoritis dalam Naskah Akademik UndangUndang No. 1 Tahun 2016 tentang Lembaga Penjaminan.

Mengacu pada undang-undang perasuransian, kedudukan lembaga reasuransi yang dimungkinkan sebagai alternatif bentuk mitigasi risiko disamping lembaga penjaminan ulang, setidaknya kedudukan lembaga reasuransi bisa dilihat dari tiga aspek yakni aspek lingkup perusahaan, lingkup usaha, dan secara khusus lingkup usaha jasa pertanggungan. Perusahaan reasuransi merupakan bagian dari usaha perasuransian dan salah satu bidang jasa usaha pertanggungan yang menjadi bagian dari usaha reasuransi adalah lembaga penjaminan.

Penelitian ini membatasi analisis pada kewajiban mitigasi resiko yang dilakukan oleh kedua lembaga tersebut, baik menurut undang-undang perasuransian maupun menurut undang-undang penjaminan. Secara khusus hadirnya lembaga reasuransi sebagai alternatif lain bentuk mitigasi risiko sebagaimana diakomodir dalam undangundang tersebut menjadi pergulatan pemikiran akademik peneliti karena antara lembaga penjaminan dan lembaga perasuransian merupakan dua skema penanganan risiko atas kredit yang berbasis pada konstruksi hukum yang berbeda. Hal tersebut melahirkan dua diskursus (pertanyaan). Pertama, bagaimana konstruksi hukum kredit dengan skema penjaminan relevansinya dengan kewajiban mitigasi

\footnotetext{
Herry Azhar Pradana, 2013, Analisis Peranan Lembaga Penjamin Kredit Daerah Dalam Pemberian Kredit Kepada Usaha Kecil Menengah, Hasil Penelitian, Balitbang Provinsi Kalimantan Selatan.

4 Undang-Undang Nomor 40 Tahun 2014 tentang Perasuransian (Lembaran Negara Republik Indonesia Tahun 2014 Nomor 337 , Tambahan Lembaran Negara Republik Indonesia Nomor 5618).
} 
risiko? Kedua, bagaimana model mitigasi risiko yang didasarkan pada kedua prinsip penanganan risiko kredit tersebut di Indonesia?

\section{B. Metode Penelitian}

Penelitian ini merupakan penelitian dengan tipe atau jenis doktrinal ${ }^{5}$ dimana hukum dikonsepsikan dan dikembangkan atas dasar doktrin. Hukum dalam penelitian ini dipandang dan diakui sebagai hukum apabila secara jelas merupakan perintah eksplisit penguasa dan dengan demikian, maka penelitian ini tidak sampai pada tahap empiris atau keberlakuan semua peraturan perundang-undangan tentang mitigasi risiko dalam penjaminan kredit.

Sebagai tipe penelitian doktrinal, maka penelitian ini menggunakan salah satu varian penelitian hukum yakni pendekatan perundangundangan (statute approach) ${ }^{6}$ yang dilakukan dengan cara menelaah semua undang-undang dan regulasi yang bersangkut paut dengan isu penelitian, dalam hal ini isu tentang mitigasi risiko dalam penjaminan kredit. Penelitian ini menelaah konsistensi antar undang-undang atau antara undang-undang dengan kebijakan mitigasi risiko dalam penjaminan kredit. Telaah ini dirancang untuk menghasilkan argumentasi dalam rangka memecahkan masalah terkait ketentuan mitigasi risiko sebagaimana diatur dalam UU No. 1 Tahun 2016.

Penelitian ini merupakan penelitian terhadap data sekunder sehingga data yang digunakan mencakup bahan hukum primer, bahan hukum sekunder, dan bahan hukum tersier. Bahan hukum primer meliputi UUD NRI Pasal 33 ayat (4), KUHPerdata tentang Subrogasi dan Penanggungan Utang, UU No. 1 Tahun 2016 tentang Penjaminan, UU No. 40 Tahun 2014 tentang Perasuransian, serta peraturan perundang-undangan terkait lainnya yang mengikat. Bahan hukum sekunder yang bersifat menjelaskan bahan hukum primer dan diperlukan dalam penelitian ini berupa Naskah Akademik UU No. 1 Tahun 2016 tentang Penjaminan dan Naskah Akademik UU No. 40 Tahun 2014 tentang Perasuransian. Penelitian ini sangat memerlukan bahan hukum tersier, terutama Kamus Ekonomi karena konten UU. No.1 Tahun 2016 sangat didominasi oleh pengetahuan ekonomi, khususnya konsep mitigasi risiko. Pengumpulan data dilakukan dengan cara library research atau penelaahan terhadap semua data sekunder, utamanya bahan hukum primer (peraturan perundang-undangan tentang penjaminan kredit dan asuransi), bahan hukum sekunder (Naskah Akademik UU No. 40 Tahun 2014 tentang Perasuransian dan UU No. 1 Tahun 2016 tentang Penjaminan), dan juga penelaahan bahan pustaka buku maupun artikel hasil penelitian terkait.

Analisis data penelitian ini dilakukan secara kualitatif yaitu semua data yang diperoleh yang berupa bahan hukum primer (KUHPerdata, UU No. 40 Tahun 2014, dan UU No. 1 Tahun 2016) disusun secara sistematis untuk selanjutnya dianalisa secara kualitatif untuk mencapai kejelasan masalah yang akan dibahas. Analisis penelitian ini mengacu pada teori tangga (Stuffen Bau Theory) Hans Kelsen terutama menganalisis taraf sinkronisasi horizontal. Merujuk pada pendapat Soerjono Soekanto ${ }^{7}$, penelitian terhadap taraf sinkronisasi horizontal tersebut didasarkan atas sampai sejauh mana suatu peraturan perundang-undangan yang mengatur berbagai bidang yang mempunyai hubungan fungsional adalah konsisten. Penelitian ini bermaksud mengukur konsistensi lembaga reasuransi sebagai salah satu bentuk mitigasi risiko dengan prinsip hukum asuransi itu sendiri serta hukum Penjaminan Hubungan antar metode terangkai dalam kesatuan pengarah penelitian ini dalam bentuk kerangka penelitian (research framework) sebagaimana tersaji dalam Gambar 1 berikut :

\footnotetext{
Soetandyo Wignyosoebroto, Hukum, Paradigma, Metode, dan Dinamika Masalahnya, 2002, Jakarta, HuMa, hlm. 147. Peter Mahmud Marzuki, 2006, Penelitian Hukum, Surabaya, Kencana Prenada Media, hlm.93.

Soerjono Soekanto, 2010, Pengantar Penelitian Hukum, Jakarta, UI Press, hlm.256.
} 


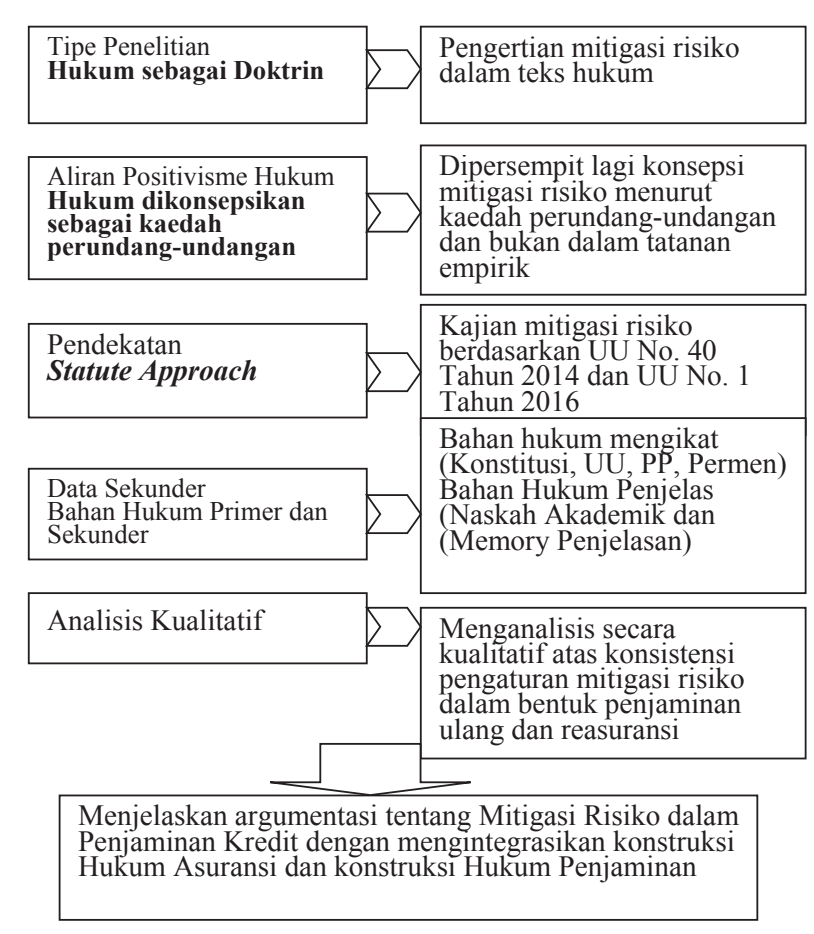

Sumber : Diolah Penulis, 2018.

Keterangan Gambar 1 :

Hukum tentang mitigasi risiko dalam penjaminan kredit secara doktrin menurut aliran positivisme merupakan perintah eksplisit penguasa/ pemegang kedaulatan. Perintah eksplisit ini kemudian dituangkan dalam UU No. 1 Tahun 2016 tentang Penjaminan dan UU No. 40 Tahun 2014 sebagai tentang Perasuransian peraturan yang mengikat bagi siapa saja yang berhubungan atau bersangkutan dengan kegiatan penjaminan kredit. Untuk mengungkapkan permasalahan, maka hanya bisa dilaksanakan dengan pendekatan perundangundangan yang berbasis pada bahan hukum mengikat (undang-undang yang bersangkutan) dan bahan hukum penjelas, baik berupa naskah akademik maupun memori penjelasan. Berbekal pada bahan hukum tersebut, maka masalah dalam hal ini terpecahkan dengan menganalisis konsistensi antarundang-undang yang mengatur tentang mitigasi risiko penjaminan kredit.

\section{Hasil Penelitian dan Pembahasan \\ 1. Konstruksi Hukum Perjanjian Kredit}

dengan Kredit Penjaminan Relevansinya dengan Mitigasi Risiko

Hadirnya UU No.1 Tahun 2016 dijadikan sebagai payung untuk semua aktivitas penjaminan di Indonesia. Penjaminan yang diatur dalam undang-undang tersebut terdiri atas penjaminan kredit atau utang piutang atau pinjam-meminjam, penjaminan atas surat utang, penjaminan pembelian barang secara angsuran, penjaminan transaksi dagang, penjaminan pengadaan barang dan/atau jasa, penjaminan bank bergaransi, penjaminan surat kredit berdokumen, penjaminan letter of credit, penjaminan kepabeanan, penjaminan cukai, penjaminan jasa konsultasi manajemen terkait dengan kegiatan usaha penjaminan dan kegiatan usaha lainnya setelah mendapat persetujuan Otoritas Jasa Keungan (OJK). Penjaminan dalam penelitian ini hanya dibatasi pada penjaminan kredit atau utang piutang. Penjaminan jenis ini diakukan dengan mekanisme pengalihan atau pelimpahan pemenuhan kewajiban debitur kepada pihak ketiga, dalam hal ini lembaga penjamin yang tak terlepas di dalamnya kewajiban mitigasi risiko yang dilakukan dengan cara menjaminulangkan kreditnya.

Sebagaimana diketahui, skema perjaminan dibedakan menjadi 2 (dua) macam terdiri atas penjaminan, termasuk penjaminan ulang, yang bersifat perorangan dan penjaminan kebendaan. Mengutip pendapat Sri Soedewi Machsoen Sofwan $^{8}$, jaminan perorangan adalah jaminan yang menimbulkan hubungan langsung pada perorangan tertentu, hanya dapat dipertahankan terhadap debitur tertentu, terhadap harta kekayaan debitur umumnya. Sebaliknya, jaminan kebendaan mempunyai ciri-ciri hubungan langsung atas benda tertentu, dapat dipertahankan terhadap siapapun, selalu mengikuti bendanya dan dapat dialihkan. Artikel ini membatasi jenis yang pertama sebagai kredit dengan skema penjaminan dan untuk yang kedua kredit dengan skema agunan. Pada kredit dengan skema agunan, hak kebendaan bersifat melekat

8 Salim H.S., 2004, Perkembangan Hukum Jaminan di Indonesia, Cetakan Pertama, Jakarta, PT. RajaGrafindo Persada, hlm.24. 
pada debitur, baik dengan penguasaan kebendaan (objek jaminan) oleh debitur (misalnya lembaga fidusia), penguasaan kebendaan oleh kreditur (lembaga gadai) maupun penguasaan yuridis kebendaan secara fisik oleh debitur penguasaan yuridis oleh kreditur (lembaga Hak Tanggungan). Apabila pada kredit dengan skema agunan ini melibatkan dua pihak yakni debitur dan kreditur, pada kredit dengan skema penjaminan terdapat tiga pihak yang mancakup debitur sebagai terjamin, kreditur sebagai penerima jaminan, dan lembaga penjaminan yang berkedudukan sebagai penjamin. Pada skema kredit berbasis agunan, apabila terjadi cidera janji, maka penyelesaiannya dilakukan dengan menjual benda jaminannya sesuai dengan lembaga jaminan yang dipilih. Hal ini berbeda dengan kredit berbasis penjaminan dimana apabila debitur wanprestasi, maka perikatan debitur diambil alih oleh lembaga penjamin dengan cara menutup utang pada kreditur dan selanjutnya hak tagih kreditur kepada debitur diambil alih oleh lembaga penjaminan. Merujuk pada ketentuan tersebut, maka hubungan hukum antara kreditur dengan lembaga penj aminan berakhir untuk dilanjutkan hubungan hukumnya dengan debitur melalui penggantian imbal jasa yang telah disepakati sebelumnya. Hubungan hukum antara debitur dengan kreditur yang kemudian karena pembayaran oleh lembaga penjamin ini, maka hubungan hukum beralih pada lembaga penjamin dan debitur.

Secara khusus, jaminan yang bersifat perorangan yang dalam tulisan ini diadopsi dalam kredit dengan skema penjaminan, argumentasi penulis mengacu pada pendapat Salim H.S. ${ }^{9}$ bahwa pada skema kredit ini berlaku 2 (dua) prinsip berupa prinsip eksistensi wanprestasi dan prinsip penagihan sekunder. Prinsip yang pertama menyatakan, tidak ada hak dan kewajiban tanpa wanprestasi. Sebagai prinsip yang kedua yang masih berkorelasi dengan peristiwa wanprestasi, apabila telah terjadi wanprestasi maka yang harus ditagih atau digugat ke pengadilan adalah pihak debitur terlebih dahulu.
Apabila debitur tidak dapat atau tidak mampu membayar sepenuhnya, juga setelah disita semua hartanya, baru bisa ditagih pihak garantornya (lembagan Penjaminannya). Prinsip penagihan sekunder sifatnya tambahan (aanvullen recht).

Apabila dicermati, baik prinsip eksistensi wanprestasi maupun prinsip penagihan sekunder, berpangkal pada peristiwa hukum wanprestasi sebagai ukuran terbit tidaknya hak dan kewajiban dari perusahaan penjaminan kepada kreditur. Disamping itu, wanprestasi juga menjadi acuan pengajuan gugatan ke pengadilan ataupun pengajuan tagihan yang tidak dibebankan langsung pada perusahaan penjaminan. Penelitian ini mengkritisi bahwa kedua prinsip tersebut hanya menjangkau pada lapisan hubungan hukum antara debitur dengan perusahaan penjaminan dan tidak sampai pada perusahaan penjaminan ulang dan perusahaan reasuransi. Perusahaan penjaminan ulang baru mengambil alih kewajiban perusahaan penjaminan apabila perusahaan ini mengalami keadaan ketidakmampuan keuangan. Lembaga reasuransi baru bertindak apabila lembaga penjaminan ulang tidak mampu untuk melakukan kewajibannya. Keberadaan lembaga reasuransi sebagai salah satu bentuk mitigasi risiko dalam penjaminan kredit bisa dianalogikan dengan salah satu kewenangan BI terhadap Bank Umum dan Badan Perkreditan Rakyat (BPR) berupa Lender of The Last Resort. Bank Indonesia berkewajiban untuk melakukan bantuan likuiditas pada saat kedua bank tersebut mengalami krisis likuiditas. Meskipun demikian, skema hukum antara lembaga penjamin kredit dengan lembaga perbankan tetap saja berbeda, terutapa pada kedudukannya. Hubungan BI dengan Bank Umum dan BPR merupakan hubungan struktural sedangkan hubungan lembaga penjamin ulang dengan lembaga reasuransi tidak bersifat struktural.

Sebagaimana diketahui, skema perjanjian kredit berbasis agunan, bersifat melekat pada debitur, baik dengan penguasaan kebendaan (objek 
jaminan) oleh debitur (misalnya lembaga fidusia), penguasaan kebendaan oleh kreditur(lembaga gadai) maupun penguasaan yuridis kebendaan secara fisik oleh debitur, dan penguasaan yuridis kebendaan oleh kreditur (lembaga Hak Tanggungan), dan pada lembaga Hipotek penguasaan yuridis adalah krediturnya sedang penguasaan bendanya ada pada debitur. Apabila pada skema ini melibatkan dua pihak yakni debitur dan kreditur, pada kredit dengan skema penjaminan terdapat tiga pihak yang mancakup debitur sebagai terjamin, kreditur sebagai penerima jaminan, dan perusahaan penjaminan yang berkedudukan sebagai penjamin. Pada skema kredit berbasis agunan, apabila terjadi cidera janji, maka penyelesaiannya dilakukan dengan menjual benda jaminannya sesuai dengan lembaga jaminan yang dipilih atau dengan kata lain penyelesaian kredit berbasis benda jaminan. Hal ini berbeda dengan kredit berbasis penjaminan dimana apabila debitur wanprestasi, maka perikatan debitur diambil alih oleh lembaga penjaminan dengan cara menutup utang pada kreditur dan selanjutnya hak tagih kreditur kepada debitur diambil alih oleh lembaga penjaminan. Berdasarkan ketentuan tersebut maka hubungan hukum antara kreditur dengan lembaga penjaminan berakhir untuk dilanjutkan hubungan hukumnya dengan debitur melalui penggantian imbal jasa yang telah disepakati sebelumnya.

Biarpun demikian, kedua lembaga ini memiliki persamaan mendasar yakni sama-sama berlandaskan pada perjanjian kredit yang bersifat dua tingkat. Sebagaimana diketahui, kredit $^{10}$ adalah penyediaan uang atau tagihan yang dapat dipersamakan dengan itu, berdasarkan persetujuan atau kesepakatan pinjam-meminjam antara bank dan pihak lain yang mewajibkan pihak peminjam untuk melunasi utangnya setelah jangka waktu tertentu dengan pemberian bunga. Kredit memuat dua level perjanjian yakni perjanjian induk atau pokok atau perjanjian prinsipil berupa perjanjian utang-piutang dan perjanjian ikutan atau assessoir berupa perjanjian pengikatan jaminan. Perjanjian ini memiliki ciri khusus yakni bahwa keberadaan dan berakhirnya perjanjian jaminan sebagai perjanjian assessoir sangat tergantung pada perjanjian prinsipilnya. ${ }^{11}$ Disamping itu, perjanjian pengikatan jaminan memuat klausul hak untuk mengambil barang jaminan sebagai pelunasan kredit debitur apabila debitur tidak membayar utangnya kepada bank atau debitur tidak memenuhi prestasinya (wanprestasi atau cidera janji) $^{12}$. Ketentuan ini membawa konsekuensi bahwa apabila perjanjian induk selesai, maka demi hukum perjanjian ikutannya juga selesai.

Perkembangan perikatan penanggungan atau penjaminan pada prinsipnya didasarkan atas konstuksi hukum subrogasi sebagaimana diatur dalam Pasal 1400 Kitab Undang-Undang Hukum Perdata (KUHPerdata). Menurut ketentuan tersebut, subrogasi diartikan sebagai perpindahan hak kreditur kepada seorang pihak ketiga yang membayar kepada kreditur, dapat terjadi karena perjanjian atau karena undang-undang. Hasil penelitian Lestari Wanasita ${ }^{13}$ menunjukkan, apabila debitur wanprestasi, maka kreditur dapat mengajukan klaim kepada perusahaan penjaminan dan klaim tersebut secara hukum beralih menjadi piutang subrogasi perusahaan penjaminan kredit. Subrogasi menjadi payung ketentuan tentang dimungkinkannya pengambilalihan pembayaran oleh pihak ketiga. Penelitian dengan tema subrogaasi juga dilakukan Yuwita, dkk ${ }^{14}$ yang menghasilkan temuan bahwa subrogasi pada prinsipnya merupakan hak penanggung yang telah memberikan ganti rugi kepada tertanggung untuk menuntut kepada pihak ketiga atau pihak lain yang menga-

10 Pasal 1 angka 12 Undang-Undang Nomor 10 Tahun 1998 tentang Perbankan (Lembaran Negara Republik Indonesia Tahun 1998 Nomor 182 , Tambahan Lembaran Negara Republik Indonesia Nomor 3790).

Hermansyah, 2008, Hukum Perbankan Nasional Indonesia, Kencana Prenada Media Group, Jakarta, hlm.71.

Sudaryat, 2008, Hukum Bisnis Suatu Pengantar, Jendela Mas Pustaka, Bandung,hlm. 74

Lestari Wanasita, 2007, Pelaksanaan Penjaminan Kredit oleh Lembaga Penjamin Kredit Bagi Usaha Kecil, Menengah dan Koperasi di Malang Jawa Timur (Studi Kasus di Perum Sarana Pengembangan Usaha Cabang Surabaya dan di PT BPD Jatim Cabang Malang, Tesis, Fakultas Hukum Universitas Muhamadiyah Malang, Malang, hlm.1.

14 Yuwita, et al., "Pelaksanaan Prinsip Subrogasi dalam Perjanjian Asuransi Kendaraan Bermotor di Banda Aceh", Jurnal Ilmu Hukum Pascasarjana Universitas Syah Kuala, Vol.2, No. 2, Agustus 2014, hlm. 6. 
kibatkan kepentingan asuransinya mengalami suatu peristiwa kerugian. Akan tetapi yang terjadi dalam praktek tertanggung tetap saja menuntut ganti rugi dari pihak ketiga yang menyebabkan kerugian dan juga mengajukan klaim asuransi atas kerugian yang dideritanya kepada pihak penanggung asuransi. Penulis kurang sepakat atas pendapat Yuwita dari temuan penelitiannya yang menempatkan para pihak, utamanya pihak ketiga dalam skema asuransi tersebut. Alasannya, rumusan Pasal 1400 KUHPerdata tersebut jelas mengatur bahwa yang dimaksud pihak ketiga dalam konteks ini adalah perusahaan asuransi dan bukan pihak yang menimbulkan kerugian. Menurut penulis, tafsir Yuwita yang menempatkan prinsip subrogasi dalam praktik asuransi kecelakaan kendaraan kurang tepat atau menyimpang dari konstruksi hukum asalnya. Ketentuan tentang subrogasi ini secara yuridis kemudian dilanjutkan dengan ketentuan khusus tentang pertanggungan utang sebagaima diatur dalam Pasal 1820 KUHPerdata.
Dikaitkan dengan perjanjian kredit atau perjanjian utang-piutang, merujuk pada Pasal 1820 KUHPerdata tersebut, penanggungan utang adalah suatu persetujuan dimana pihak ketiga demi kepentingan kreditur, mengikatkan diri untuk memenuhi perikatan debitur, bila debitur tidak memenuhi perikatannya atau cidera janji/ wanprestasi. Baik subrogasi maupun perjanjian penanggungan utang masih membatasi pada alas hukum pengambilalihan atau pelimpahan tanggung jawab atas tidak dipenuhinya perikatan oleh debitur. Meskipun dasarnya mengikuti kedua lembaga tersebut, penjaminan utang sebagaimana diatur dalam UU No. 1 Tahun 2016 mewajibkan mitigasi risiko sebagai dasar keyakinan kreditur apabila perusahaan penjaminan mengalami kesulitan finansial sehingga prinsip kepercayaan antara debitur dan kreditur tetap terjaga.

Konstruksi hukum skema kredit berbasis penjaminan tersaji dalam Gambar 2 berikut :

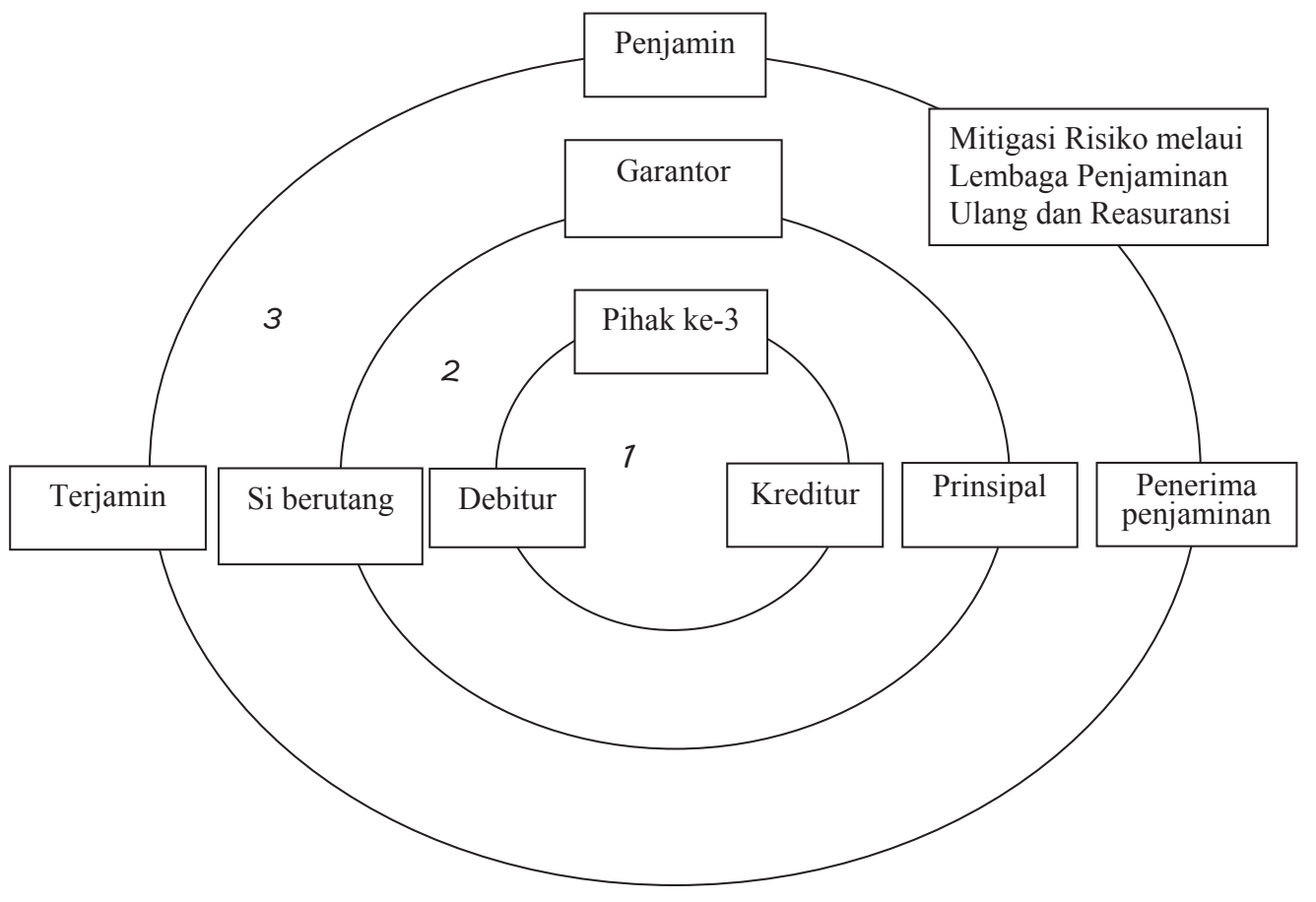

Penjelasan Gambar 2 :

Masing lingkaran menggambarkan para pihak pada masing-masing lembaga, dimulai dari lingkaran paling kecil (subrogasi sebagai lembaga pembayaran), lapisan lingkaran berikutnya (lembaga penanggungan utang) dan lingkaran terluar atau terakhir adalah lembaga penjaminan yang melekat di dalamnya kewajiban mitigasi risiko. Alasan latar 
belakang gambar lingkaran adalah karena ketiga lembaga didasarkan atas perikatan yang sama yakni perikatan kredit.

Lembaga subrogasi, yang dalam gambar 2 (dua) tersebut, bersifat paling umum, merupakan landasan bagi lembaga penanggungan utang karena memungkinkan pengalihan hak kreditur kepada pihak ketiga yang telah membayar kepadanya (kreditur). Meskipun demikian, ketiganya memiliki kesamaan yakni adanya hubungan hukum utang-piutang atau pinjam-meminjam antara debitur-kreditur (subrogasi), penerima penanggungan-pemberi penanggungan (lembaga penanggungan utang), dan penjamin-terjamin (lembaga penjaminan). Pada kredit dengan skema penjaminan terdapat satu hubungan hukum yang tidak ditemukan pada dua lembaga yang telah mendapatkan pengaturan sebelumnya yakni hadirnya hubungan hukum penjaminan ulang. Lembaga yang merupakan bentuk mitigasi risiko ini melekat secara otomatis dalam perusahaan penjaminan. Sampai dengan tahun 2011, sepanjang pengetahuan penulis, lembaga penjamin kredit di Indonesia tidak disertai dengan kewajiban mitigasi risiko secara tegas sebagaimana diatur dalam UU No. 1 Tahun 2016.

\section{Model Mitigasi Risiko pada Perjanjian Penjaminan Kredit di Indonesia}

Sebelum merujuk pengertian mitigasi risiko yang telah bersifat mengikat sebagaimana diatur dalam berbagai peraturan perundang-undangan, ada baiknya bila ditelusuri terlebih dahulu hakikat mitigasi risiko dengan meminjam dari lapangan ilmu lain.Mitigasi menurut National Research Council diartikan sebagai:"reduction of the likelihood that a risk event will occur and/or reduction of the effect of a risk even if it does occur". Selanjutnya "...risk mitigation strategies and specific action plan should be incorporated in the project execution plan,..." Berdasarkan uraian tersebut, secara singkat mitigasi risiko diartikan sebagai suatu sistem perencanaan untuk mengurangi atas kemungkinan terjadinya risiko dari kegiatan bisnis dan mitigasi tersebut melekat dalam perencanaan projek atau kegiatan.

Mitigasi risiko ${ }^{15}$ merupakan bagian dari proses manajemen risiko yang salah satunya berupa kewajiban untuk menyusun rencana mitigasi ataurespon risiko dengan tujuan memperkecil eksposur risiko. Standar manajemen risiko COSO Integrated Framework 2004 dan ISO 310002009 menyebutkan empat strategi mitigasi risiko yang mencakup hindari (avoid), kurangi (reduce), berbagi dengan pihak ketiga (share), dan terima (accept);

Berdasarkan pengertian mitigasi risiko bisa dilihat dari berbagai perspektif manajemen risiko secara umum, strategi perencanaan projek tertentu serta dari lembaga standardisasi mutu. Mitigasi risiko dalam perspektif ini lebih pada upaya pengurangan kemungkinan risiko selama kegiatan organisasi berlangsung dan ancang-ancang atau antisipasi risiko yang mungkin terjadi.

Berbeda dengan dua sudut pandang pengertian mitigasi risiko sebelumnya, menurut ISO tersebut, mitigasi risiko didasarkan atas strategi tertentu yang memuat empat hal. Pilihan-pilihan yang memungkinkan tersebut, menurut pendapat penulis tidak sesuai dengan konteks hukum lembaga penjaminan di Indonesia. Alternatif nomor empat merupakan pilihan yang paling mendekati namun tetap saja kurang tepat karena pendekatan mitigasi risiko di Indonesia didasarkan pada pengalihan pelaksanaan perikatan debitur pada lembaga penjaminan dan lembaga penjaminan ulang dan bukan berbagi dengan kedua lembaga tersebut. Prinsip berbagi risiko lebih tepat untuk penjaminan ulang syari'ah sehingga artikel ini merujuk pengertian mitigasi risiko pada UU No. 1 Tahun 2016.

Apabila ditelusuri, mitigasi risiko dalam bentuk reasuransi di Indonesia bisa disimak dari rumusan Pasal 271 KUHDmeskipun dalam pengaturan yang sangat terbatas. Rumusan pasal berbunyi : "Si penanggung selamanya berkuasa 
untuk sekali lagi mempertanggungkan apa yang telah ditanggung olehnya”. Terhadap redaksi pasal tersebut, Emmy Pangaribuan Simanjuntak ${ }^{16}$ berpendapat bahwa dalam praktek, perusahaan reasuransi berkembang sangat pesat dan pada umumnya para penanggung bertanggung jawab untuk mempertanggungkan kembali atas pertanggungan yang mereka tutup dengan tujuan demi menjaga terjaminnya pertanggungjawabannya dalam hal terjadi kerugian. Disamping itu, pertanggungan kembali juga memiliki tujuan lain yakni menjaga kelestarian usaha. Praktik perjanjian kredit menunjukkan analogi perkembangan Pasal 271 tersebut dimana perikatan debitur dilimpahkan atau dialihkan pada pihak ketiga yakni lembaga reasuransi. Penulis perlu sekali lagi menyampaikan bahwa konteks Pasal 271 adalah pertanggungan dalam skema asuransi dan bukan dalam skema penjaminan karena skema penjaminan lebih tepat merujuk pada penanggungan utang sebagaimana telah dibahas dalam pembahasan masalah nomor satu.

Dasar yang bersifat mengikat tentang pengertian mitigasi risiko dapat ditelusuri dalam peraturan perundang-undangan. UU No. 1 Tahun 2016, baik dalam teks pasalnya, memori penjelasannya, maupun naskah akademiknya tidak memberikan pembatasan tentang pengertian mitigasi risiko. Secara tekstual, undang-undang tersebut hanya mengatur dengan cara apa mitigasi risiko dilakukan. Bentuk mitigasi risiko sebagaimana diatur dalam Pasal 42 dilakukan melalui lembaga penjaminan ulang dan reasuransi. Hal tersebut berbeda dengan UU No. 40 Tahun 2014 tentang Perasuransian mengatur secara tegas sebagaimana tertulis pada Pasal 19 ayat (3) dimana kewajiban merencanakan dan menerapkan metode mitigasi risiko adalah dalam rangka menjaga kesehatan keuangannya. Tentang detail bagaimana mitigasi risiko dilaksanakan diatur lebih lanjut dalam Surat Edaran Otoritas Jasa Keuangan No. 10/SEOJK.05/2016 tentang Pedoman Penerapan Manajeman Risiko bagi Lembaga Jasa Keuangan Nonbank. Sekedar membandingkan, perusahaan pembiayaan juga diwajibkan untuk melakukan mitigasi risiko pembiayaan yang dilakukan dengan tiga alternatif cara yakni mengalihkan risiko pembiayaan melalui asuransi kredit atau penjaminan kredit, mengalihkan risiko atas barang yang dibiayai atau barang yang menjadi agunan dari kegiatan pembiayaan melalui mekanisme asuransi dan/atau melakukan pembebanan jaminan fidusia atas barang yang dibiayai atau barang yang menjadi agunan dari kegiatan pembiayaan. Sedangkan penjaminan ulang adalah pengambilalihan tanggung jawab penjamin (lembaga penjaminan) atas ketidakmampuan finansial terjamin atas kemungkinan wanprestasi dalam membayar angsuran atau kredit sesuai dengan perjanjian utang piutang antara terjamin (debitur) dengan penerima jaminan (kreditur). Terminologi 'reasuransi' atau asuransi kembali adalah pengmbilalihan tanggung jawab dari lembaga asuransi atas kegagalan finansial lembaga tersebut dalam membayarkan premi kepada tertanggung. Pasal 1 angka 23 mengatur bahwa yang dimaksud dengan tertanggung adalah pihak yang menghadapi risiko sebagaimana diatur dalam perjanjian asuransi atau perjanjian reasuransi. Dalam konteks perasuransian, sebagaimana tertuang pada Pasal 1 huruf (a) Undang-Undang nomor 40 tahun 2014 tentang Perasuransian, pemberian penggantian kepada tertanggung atau pemegang polis adalah karena kerugian, kerusakan, biaya yang timbul, kehilangan keuntungan, atau tanggung jawab hukum kepada pihak ketiga yang mungkin diderita tertanggung atau pemegang polis karena peristiwa yang tidak pasti.

Perbandingan skema mitigasi risiko antara Lembaga Penjaminan Ulang dan Lembaga Reasuransi tersaji dalam Gambar 3 berikut :

16 Emmy Pangaribuan Simanjuntak, 1980, Hukum Pertanggungan (Pokok-pokok Pertanggungan Kerugian, Kebakaran, dan Jiwa), Seksi Hukum Dagang Universitas Gadjah Mada, Yogyakarta, hlm. 107. 


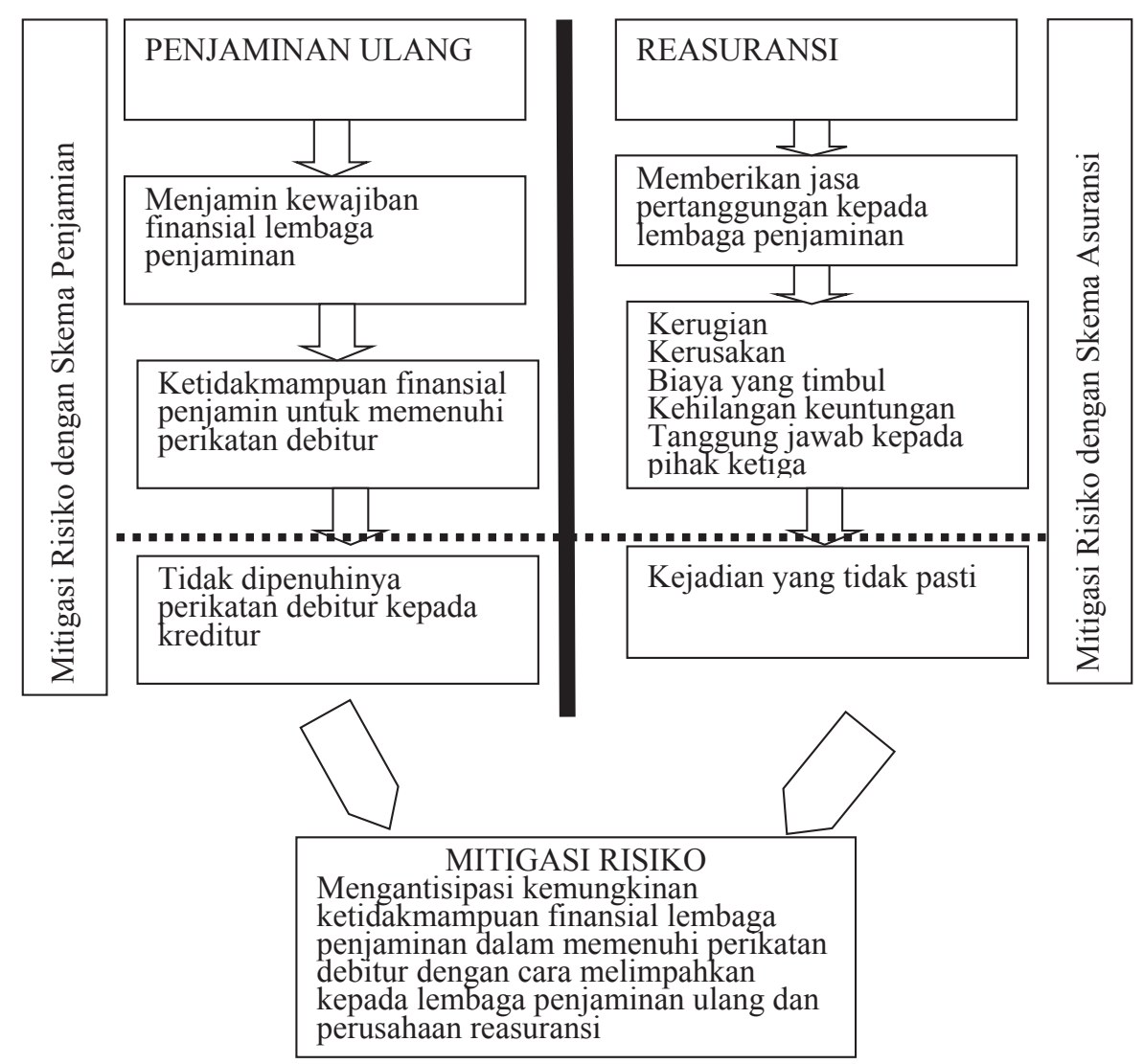

Gambar 3: Model Mitigasi Risiko pada Lembaga Penjaminan Kredit di Indonesia

Penjelasan Gambar 3 :

UU No. 40 Tahun 2014 tentang Perasuransian meluaskan objek pemberian jasa pertanggungan kepada lembaga penjaminan oleh perusahaan reasuransi. Sebaliknya, UU No. 1 Tahun 2016 juga memungkinkan kewajiban mitigasi risiko oleh perusahaan reasuransi dengan ketentuan apabila lembaga penjaminan tidak mendapatkan dukungan dari lembaga penjaminan ulang. Dari rumusan tersebut dapat disimpulkan bahwa keberadaan lembaga reasuransi bersifat pilihan atau alternatif. Persingungan kedua undang-undang tersebut perlu dianalisis, terutama didasarkan atas konsistensi konstruksi lembaga asalnya dimana mereka berasal dari dua lembaga yang berbeda (lembaga asuransi dan lembaga penjaminan)Pada Gambar 3 terlihat bahwa jasa pertanggungan baru diberikan oleh perusahaan reasuransi apabila mengalami kerugian, kerusakan, biaya yang timbul, kehilangan keuntungan serta tanggung jawab pada pihak ketiga yang disebabkan karena kejadian yang tidak pasti. Sementara pada perusahaan penjaminan ulang, penjaminan ulang baru dilakukan apabila Lembaga Penjamin mengalami kesulitan dalam memenuhi kewajiban finansialnya. Tulisan ini perlu menyandingkan kejadian yang tidak pasti pada lembaga reasuransi dengan kemungkinan wanprestasi yang dilakukan oleh debitur pada lembaga penjaminan ulang. Apabila dilihat dari sumber hukumnya, kedua undang-undang tersebut sama-sama berkedudukan sebagai sumber hukum formal yang memiliki kekuatan berlaku yang sama. Oleh karena itu, untuk menentukan mana diantara undang-undang tersebut yang berlaku, maka merujuk pendapat Sotandyo Wignyosoebroto ${ }^{17}$ harus menelusurinya dari khazanah doktrin atau ajaran. 
Salah satu doktrin yang dikenal dalam Ilmu Hukum adalah berlakunya azas "Lex specialis derogate legi generalis" yang memuat arti bahwa hukum yang khusus (mitigasi risiko pada lembaga penjaminan kredit yang diatur dalam Undang-undang No. 1 Tahun 2016) mengesampingkan hukum yang umum (prinsip mitigasi risiko secara umum. Perlu dipertegas dalam tulisan ini, kekhususan norma hukumnya terletak pada 'mitigasi risiko' yang khusus berlaku pada penjaminan kredit dan bukan pada lembaga yang lain.

Gambar ini juga secara jelas mengilustrasikan bahwa pada level pertama sama-sama menampilkan hubungan hukum dua pihak (sama dengan konstruksi hukum asuransi) yakni antara lembaga penjaminan ulang dan lembaga reasuransi dengan lembaga penjaminan. Namun demikian, pada alur ataulevel di bawahnya terlihat inkonsistensi sebagaimana hasil analisis sebelumnya.

Hubungan hukum para pihak dapat diilustrasikan sebagai berikut :

Hubungan hukum antara lembaga penjamin dengan lembaga penjaminan ulang adalah hubungan hukum perjanjian penjaminan ulang. Hubungan hukum antara lembaga penjaminan dengan kreditur adalah hubungan hukum perjanjian penjaminan, sedangkan hubungan hukum antara kreditur dengan debitur adalah hubungan hukum perjanjian kredit yang terikat pada dua lapis perjanjian yakni perjanjian utang-piutang dan perjanjian pernjaminan. Ketiga kerangka hubungan hukum tersebut, menurut Munir Fuady ${ }^{18}$ dikategorikan sebagai jamninan perorangan. Kerangka ini menerbitkan hak-hak yang bersifat kontraktual yang berarti bahwa pihak kreditur hanya dapat mempertahankan haknya terhadap pihak garantor saja dan tidak berlaku pada pihak-pihak lainnya. Kewajiban dan hak hanya mengikat para pihak yang terlibat dalam perjanijan penjaminan tersebut. Ketentuan ini berbeda dengan jaminan kebendaan seperti gadai, hak tanggungan, fidusia, serta hipotik yang terhadapnya berlaku prinsip droit de suit dimana hak kebendaan mengikuti bendanya.

\section{Kesimpulan}

Keberadaan kredit dengan skema lembaga penjaminan sebenarnya telah mendapatkan pengaturan dalam KUHPerdata berupa lembaga subrogasi dan lembaga penanggungan utang. Namun lembaga penjaminan kredit sebagaimana diatur dalam UU No. 1 Tahun 2016 mengalami perkembangan dengan adanya kewajiban mitigasi risiko untuk meyakinkan para pihak, baik terkait kemungkinan tidak dilaksanakannya perikatan antara debitur dan kreditur maupun kemungkinan kegagalan finansial yang melanda lembaga penjaminan.

Model mitigasi risiko didasarkan atas integrasi UU No. 40 Tahun 2014 (perluasan objek jasa pertanggungan perusahaan reasuransi) dengan UU No. 1 Tahun 2016 (dimungkinkannya penggunaan lembaga reasuransi apabila lembaga penjamin tidak mendapatkan dukungan dari lembaga penjamin ulang) dalam melakukan mitigasi risiko. Penelitian ini menemukan inkonsistensi lembaga reasuransi sebagai bentuk mitigasi risiko dengan konstruksi hukum asuransi yang mendasarinya. Dengan demikian, peran lembaga reasuransi sebagai bentuk mitigasi risiko terlalu lemah argumentasi yuridisnya

Berdasarkan hasil kajian tentang perluasan objek penyediaan jasa pertanggungan oleh perusahaan reasuransi terhadap lembaga penjaminan sebagai bentuk mitigasi risiko, ditemukan inkonsistensi pada taraf sinkronisasi horisontal. Apabila hal ini dibiarkan, maka akan berpotensi menimbulkan kekacauan yuridis sehingga penulis menyarankan agar dilakukan perubahan terhadap kedua peraturan perundang-undangan tersebut sehingga terjamin kepastian hukumnya.

18 Munir Fuady, 2013, Hukum Jaminan Utang, Cetakan Pertama, Jakarta Erlangga, hlm 183. 


\section{DAFTAR PUSTAKA}

\section{A. Buku}

Fuady, Munir, 2013, Hukum Jaminan Utang, Cetakan Pertama, Jakarta Erlangga.

Hermansyah, 2008, Hukum Perbankan Nasional Indonesia, Kencana Prenada Media Group, Jakarta.

Marzuki, Peter Mahmud, 2006, Penelitian Hukum, Surabaya, Kencana Prenada Media.

S., Salim H., 2004, Perkembangan Hukum Jaminan di Indonesia, Cetakan Pertama, Jakarta, PT. RajaGrafindo Persada.

Simanjuntak, Emmy Pangaribuan, 1980, Hukum Pertanggungan (Pokok-pokok Pertanggungan Kerugian, Kebakaran, dan Jiwa), Seksi Hukum Dagang Universitas Gadjah Mada, Yogyakarta.

Sudaryat, 2008, Hukum Bisnis Suatu Pengantar, Jendela Mas Pustaka, Bandung.

Soekanto, Soerjono, 2010, Pengantar Penelitian Hukum, UI Press, Jakarta.

Wignjosoebroto, Soetandyo, 2002, Hukum, Paradigma, Metode, dan Dinamika Masalahnya, Jakarta, HuMa.

\section{B. Jurnal}

Yuwita, et al., "Pelaksanaan Prinsip Subrogasi dalam Perjanjian Asuransi Kendaraan Bermotor di Banda Aceh", Jurnal Ilmu Hukum Pascasarjana Universitas Syah Kuala, Vol.2, No. 2, Agustus 2014.

\section{Hasil Penelitian/Tugas Akhir}

Pradana, Herry Azhar, 2013, Analisis Peranan Lembaga Penjamin Kredit Daerah Dalam Pemberian Kredit Kepada Usaha Kecil Menengah, Hasil Penelitian, Balitbang Provinsi Kalimantan Selatan.

Sofiati, Hetty, 2003, Lembaga Penjaminan Kredit bagi Usaha Kecil dan Menengah, Laporan Penelitian, BPHN, Jakarta.

Wanasita, Lestari, 2007, Pelaksanaan Penjaminan Kredit bagi UMKM di Malang, Tesis,
Universitas Muhamadiyah Malang. , 2007, Sebuah Pedoman Ringkas tentang Tata Cara Penulisannya, Disertasi, FISIP UNAIR, Surabaya.

\section{Internet}

Wahyudi, Irham, "Strategi Mitigasi Risiko", www. apb-group.com/strategi-mitigasi-risiko-1/, diakses 17 Oktober 2017.

\section{E. Peraturan Perundang-undangan}

Kitab Undang-Undang Hukum Perdata.

Kitab Undang-Undang Hukum Dagang.

Undang-Undang Nomor 10 Tahun 1998 tentang Perbankan (Lembaran Negara Republik Indonesia Tahun 1998 Nomor 182, Tambahan Lembaran Negara Republik Indonesia Nomor 3790) .

Undang-Undang Nomor 40 Tahun 2014 tenang Perasuransian (Lembaran Negara Republik Indonesia Tahun 2014 Nomor 337, Tambahan Lembaran Negara Republik Indonesia Nomor 5618 .

Undang-Undang Nomor 1 Tahun 2016 tentang Penjaminan (Lembaran Negara Republik Indonesia Tahun 2016 Nomor 9, Tambahan Lembaran Negara Republik Indonesia Nomor 5835.

Peraturan Otoritas Jasa Keuangan nomor 29/ POJK.05/2014.

Surat Edaran Otoritas Jasa Keuangan No. 10/ SEOJK.05/2016 tentang Pedoman Penerapan Manajeman Risiko dan Laporan Hasil Penilaian Sendiri Penerapan Manajemen Risiko bagi Lembaga Jasa Keuangan Nonbank.

\section{F. Dokumen Lain}

Sekretariat Dewan Perwakilan Rakyat (DPR) RI, Rancangan Undang-Undang tentang Lembaga Penjaminan, 2015. 